Historic, Archive Document

Do not assume content reflects current scientific knowledge, policies, or practices. 



\section{A99.9 \\ F76324 \\ Effects of Harvesting Ponderosa Pine on Nongame Bird Populations}

Robert C. Szaro and Russell P. Balda

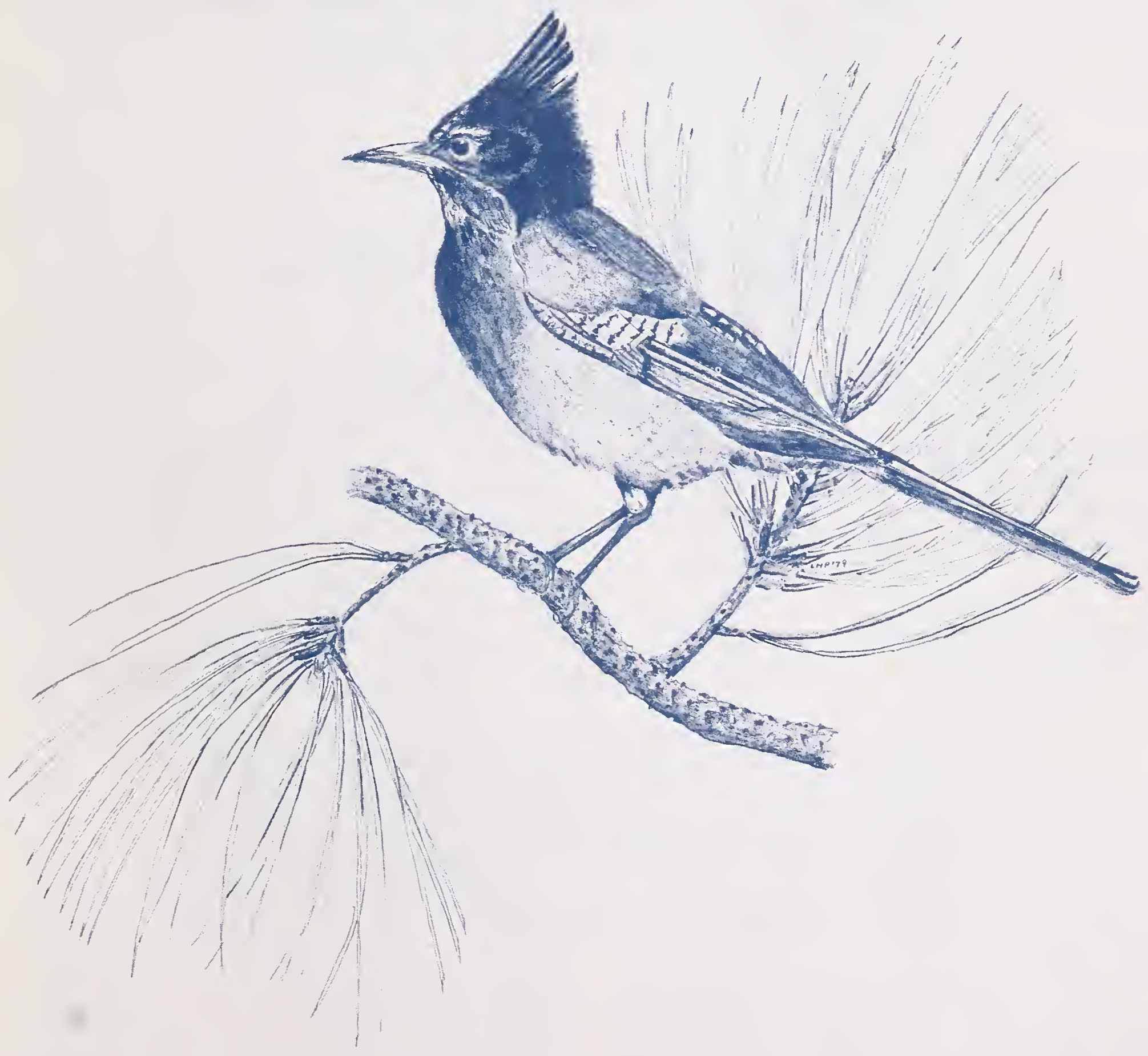

Research Paper RM-212

Rocky Mountain Forest and

Range Experiment Station

Forest Service

U.S. Department of Agriculture 


\title{
Effects of Harvesting Ponderosa Pine on Nongame Bird Populations
}

\author{
Robert C. Szaro, Research Wildlife Biologist \\ Rocky Mountain Forest and Range Experiment Station ${ }^{1}$ \\ and \\ Russell P. Balda, Professor of Biology \\ Northern Arizona University
}

\begin{abstract}
Bird species diversity and species richness in the ponderosa pine forest were not significantly affected by forest cutting and logging except on the clearcut plot. Bird population densities were significantly increased on the silviculturally cut and irregular strip shelterwood plots and were significantly decreased on the severely thinned and clearcut plots. Guidelines are recommended that will allow substantial logging of the ponderosa pine forest while still maintaining bird density, diversity, and species richness.
\end{abstract}




\title{
246 \\ Effects of Harvesting Ponderosa Pine \\ on Nongame Bird Populations.
}

\author{
Robert C. Szaro and Russell P. Balda
}

\section{Management Implications}

The forest manager can remove between onesixth and two-thirds of the available foliage of the ponderosa pine forest either in strips (and probably in blocks) or by thinning without detrimentally affecting the breeding bird community in terms of species richness, density, and diversity. Increased densities on silviculturally cut and irregular strip shelterwood plots are probably at least partially due to openings (MacArthur et al. 1962; Marshall 1957, 1963). However, forest treatments must consider that the quality of the bird community on cut and control areas are not equal. Species found on the control plot, such as the hermit thrush, red-faced warbler, western flycatcher, and pygmy nuthatch, are replaced on the cut areas by species such as the western wood pewee, yellow-rumped warbler, and rock wren.

When forests are managed for tree and/or water yield, some specific guidelines can be followed to minimize the impact of habitat modification on bird populations. To simply state that foliage volume can be reduced by one-sixth to two-thirds is of little real significance to forest managers. Foliage volume is important to the birds because it is related to the resource base but is difficult and time consuming to measure. Therefore, to maintain and/or increase (by up to $35 \%$ ) ponderosa pine forest bird populations, the following guidelines are recommended:
1. The total basal area of a given stand can be reduced by $15 \%$ to $50 \%$. However, largescale removal should be in strips or blocks. In a uniform thinning operation, consider removing only $30 \%$ of the total basal area.

2. Remove no more than $45 \%$ of those trees with a d.b.h. of 9 inches or greater. Leave a minimum of 32 trees per acre.

3. Remove no more than $75 \%$ of those trees with a d.b.h. between 6 and 9 inches. Leave a minimum of 17 trees per acre.

4. Remove $80 \%$ of the trees with a d.b.h. between 3 and 6 inches leaving approximately 25 trees per acre.

5. Gambel oak should not be removed at all. If absolutely necessary, remove no more than $25 \%$ of the oaks.

6. Several overmature trees per acre should be left to allow for adequate snag recruitment.

7. Snags should be left as nesting and roosting sites for cavity nesters. Balda (1975) suggests 2.6 snags per acre.

These guidelines are based on a comparison between the control plot and the silviculturally cut and the irregular strip shelterwood plots.

\section{Introduction}

Avian ecologists have long been interested in relating breeding bird populations to the vegetation of an area (Beecher 1942, Johnston and Odum 1956, Bond 1957). As the structure of a habitat becomes more complex, the number of different bird species increases (Karr 1968, MacArthur and MacArthur 1961, MacArthur et al. 1966, Recher 1969). The population density of blackburnian warblers ${ }^{2}$ and myrtle warblers appears to be closely correlated with foliage volume (MacArthur 1958). Moreover, foliage volume may

${ }^{2}$ Common and scientific names of all birds and trees referred to in this paper are listed in the appendix. be an important factor limiting the densities of parula warblers and nuthatches (Balda 1969, Morse 1967). Data by Balda (1969) strongly suggest that removing tall ponderosa pines (40 to 70 feet) may have a negative effect on the density of Grace's warblers; whereas the removal of the understory may reduce the populations of the gray-headed junco and the chipping sparrow.

Bird population densities in a particular habitat are believed to be regulated by many factors. Any alteration of that habitat may affect the suitability of the habitat for a given species' niche requirements. This study examined effects of timber management practices on bird populations and ways these practices can be used to manage nongame bird populations. 


\section{Study Areas}

Five study plots were chosen in relatively homogeneous stands of ponderosa pine with a buffer around the periphery of at least 330 feet. Study plots contained about the same proportions of different size classes of trees and density of Gambel oak. All study areas were set up as 35-acre plots except for the study area on the clearcut watershed, which encompassed 100 acres.

The five study areas are in the Coconino National Forest, Coconino County, Arizona. All the areas are located within a 13-mile radius on the Beaver Creek Watershed. The areas included a clearcut, a severely thinned, an irregular strip shelterwood, a silviculturally cut (individual tree selection), and a control plot. All study sites were cut before the study begán except for the silviculturally cut area, which was cut during the spring of 1974.

The ponderosa pine vegetation type, which was found on all study areas before treatment, is found primarily in areas of brolliar, siesta, and sponsellar soils (Williams and Anderson 1967).

\section{Control Plot}

The control is located on watershed 13 approximately 41 miles southeast of Flagstaff at an elevation of 7,200 feet. The study area is on a southwest-facing slope of about $17^{\circ}$, in the west-central portion of the 368-acre watershed.

Watershed 13 was left untreated as the control area. Ponderosa pine was the dominant tree species with an importance value of 253 (table 1). There were approximately 262 trees per acre with a canopy volume of 276,800 cubic feet per acre and a total basal area of 116.3 square feet per acre. Of the trees of the plot, $78 \%$ had a d.b.h. of 9 inches or smaller (table 2). In fact, the control plot had 3.7 times as many trees with a d.b.h. between 3 and 6 inches than any other study plot (table 2).

\section{Silviculturally Cut Plot}

The silviculturally cut plot is located on watershed 8, approximately 39 miles southeast of Flagstaff at an elevation of 7,400 feet. The study area is on a west-facing slope of about $13^{\circ}$, in the southwest corner of the 1,800-acre watershed.

The prescription called for stands made up of trees smaller than 10 inches d.b.h. to be thinned to a growing stock level of 60 square feet per acre of basal area. ${ }^{3}$ Stands consisting of trees 12 inches d.b.h. and larger were thinned to an actual 70 square feet per acre of basal area. Trees were cut to upgrade the stand rather than to obtain uniform spacing. In most cases, Gambel oak were left intact.

The treatment was completed in early spring 1974; ponderosa pine was the major dominant tree species with an importance value of 263.4 (table 1). There were approximately 96 trees per acre with a canopy volume of 243,500 cubic feet per acre. This amounted to a reduction of $28.9 \%$ in the available foliage. The total basal area for all tree species was 101.5 square feet per acre.

\section{Irregular Strip Shelterwood Plot}

The irregular strip shelterwood cut plot is located on watershed 14, approximately 42 miles southeast of Flagstaff, at an elevation of 7,050 feet. The study area is on a south-facing slope of about $9^{\circ}$, in the southeast corner of the 546-acre watershed.

The objective of the treatment was to increase water yield while at the same time providing good timber production and pleasing esthetics (Brown et al. 1974). Clearcut strips were designed primarily to increase streamflow. The alternative "leave" strips were thinned to improve production.

The pattern was one of alternate cut and leave strips. The cut and leave strips averaged 60 and 120 feet in width, respectively. Irregular-shaped spacers of uncut trees, 50 to 70 feet long, at intervals of about 400 feet, were left in the cut strips to break up the visual continuity. Most of the Gambel oak were left in the cut strips; where there was enough oak to break up the continuity of the strips it was not necessary to use spacers. Width of the clearcut area within any strip varied as much as $50 \%$ (i.e., $120 \pm 60$ feet) to provide an esthetically pleasing, irregular pattern of elongated openings.

The treatment was completed in spring 1970. Ponderosa pine was the dominant tree species with an importance value of 228.2 (table 1). There were approximately 74 trees per acre with a canopy volume of 92,700 cubic feet per acre and a total basal area of 54 square feet per acre.

\section{Severely Thinned Plot}

The severely thinned plot is located on watershed 17 , approximately 27 miles south of Flagstaff at an elevation of 6,860 feet. The study area is on

\footnotetext{
'Personal communication with Fred Larson, Research Forester, USDA Forest Service, Flagstaff, Ariz.
} 
Table 1.-Composition of trees on all forested study areas

\begin{tabular}{|c|c|c|c|c|c|c|}
\hline Species & $\begin{array}{l}\text { Relative } \\
\text { density }\end{array}$ & $\begin{array}{c}\text { Relative } \\
\text { dominance }\end{array}$ & $\begin{array}{c}\text { Relative } \\
\text { frequency }\end{array}$ & $\begin{array}{l}\text { Importance } \\
\text { value }\end{array}$ & $\begin{array}{l}\text { Absolute } \\
\text { density }\end{array}$ & $\begin{array}{c}\text { Total foliage } \\
\text { volume }\end{array}$ \\
\hline & (percent) & (percent) & (percent) & (index) & (trees per acre) & (ft $\left.t^{3} / a c r e\right)$ \\
\hline \multicolumn{7}{|l|}{ Control } \\
\hline Ponderosa pine & 90.1 & 85.7 & 77.0 & 252.8 & 236 & 234,900 \\
\hline Gambel oak & 8.4 & 8.3 & 19.3 & 36.0 & 22 & 28,700 \\
\hline Alligator juniper & 1.5 & 6.0 & 3.7 & 11.2 & 4 & 13,200 \\
\hline \multicolumn{7}{|l|}{ Silviculturally cut } \\
\hline Ponderosa pine & 91.5 & 92.5 & 79.4 & 263.4 & 88 & 202,500 \\
\hline Gambel oak & 8.5 & 7.5 & 20.6 & 36.6 & 8 & 41,000 \\
\hline \multicolumn{7}{|c|}{ Irregular strip shelterwood } \\
\hline Ponderosa pine & 79.1 & 82.0 & 67.1 & 228.2 & 59 & 62,000 \\
\hline Gambel oak & 20.4 & 15.7 & 31.5 & 67.6 & 14 & 30,300 \\
\hline Alligator juniper & 0.5 & 2.3 & 1.4 & 4.2 & 1 & 400 \\
\hline \multicolumn{7}{|l|}{ Severely thinned } \\
\hline Ponderosa & 86.8 & 91.9 & 74.3 & 253.0 & 24 & 48,500 \\
\hline Gambel oak & 13.2 & 8.1 & 25.7 & 47.0 & 4 & 8,600 \\
\hline
\end{tabular}

Table 2.-Tree size distribution on all forested study areas (trees per acre)

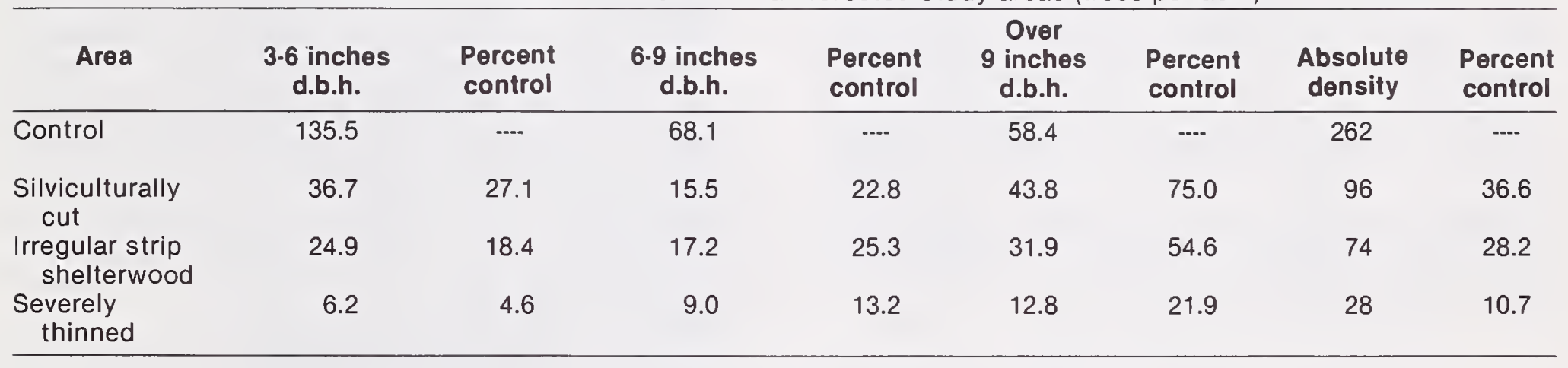

a southwest-facing slope of about $8^{\circ}$, in the southwest corner of the 121-acre watershed.

Treatment was intended to provide a reasonable opportunity for increased water yield while leaving a lightly stocked timber stand that could be subjected to even-aged management (Brown et al. 1974). Slash was piled in strategically arranged windrows. Windrows were piled as high and narrow as possible to maximize snow trapping and retention. Windrows were arranged with 30 -foot breaks at intervals of 200 feet or less to reduce possible fire spread.

Treatment was completed in spring 1969. Ponderosa pine was the dominant tree species with an importance value of 253 (table 1). There were approximately 28 trees per acre with a canopy volume of 57,100 cubic feet per acre and a total basal area of 22.2 square feet per acre.

\section{Clearcut Study Plot}

The clearcut plot is located on watershed 12 , approximately 43 miles southeast of Flagstaff at an elevation of 7,040 feet. The study area is on a southwest-facing slope of about $10^{\circ}$, in the southeast corner of the 200-acre watershed.

The treatment was designed to test the effects of clearcutting all the woody vegetation on the watershed and windrowing the resultant slash (Brown et al. 1974). All wood products that could be sold were removed from the watershed. The remaining slash and debris were machine windrowed in such a way as to trap and retain snow, reduce evapotranspiration losses, and increase the drainage efficiency of the watershed. In areas of heavy slash, the windrows were at least 5 feet high and were spaced about 100 feet apart. In areas of lighter slash, the windrows were spaced further apart to achieve the minimum height. Windrows were placed in either an east-west or northeast-southwest direction.

The treatment was completed in spring 1967. Since that time, there has been considerable shrubby growth by Gambel oak next to the slash windrows. 


\section{Methods and Materials}

Tree measurements were made on all plots except the clearcut site. The plotless point-quarter method (Cottam and Curtis 1956) was used to sample trees with a d.b.h. of 3 inches or larger. A grid composed of 104 points (416 trees) was sampled on each plot. These data were then analyzed using the standard formulas of Cottam and Curtis (1956) to obtain the following: absolute density, relative dominance, relative frequency, relative density, and importance value. The following additional data were also recorded for the trees sampled at each point: total tree height, height from the ground to the lowest live limb, and outer crown diameter at the lowest live limb. Tree crowns were classified as conical, cylindrical, or hemispherical. Tree crown data were then analyzed and expressed in terms of foliage (or crown) volume.

Breeding bird counts were made during the 1974 and 1975 breeding seasons using the spotmap method described by Kendeigh (1944). Ten censuses were taken each year on each study site. Population densities were averaged for the 2-year period to eliminate effects of climatic fluctuations.

Species diversity $\left(\mathrm{H}^{\prime}\right)$ (Shannon and Weaver 1948) was calculated on the mean densities for all plots by the following formula:

$$
\mathrm{H}^{\prime}=-\Sigma \mathrm{P}_{\mathrm{i}} \ln \left(\mathrm{P}_{\mathrm{i}}\right)
$$

where $\mathrm{P}_{\mathrm{i}}$ is the proportion of a given bird species present. Evenness (E) was calculated by the following:

$$
\mathrm{E}=\mathrm{H}^{\prime} / \ln \mathrm{S}
$$

where $\mathrm{S}$ is the number of species present (richness).

\section{Bird Community Composition}

The effects of habitat alteration on species composition and densities have been examined in areas where the habitat was altered by logging (Hagar 1960; Kilgore 1971; Lack 1933, 1939; Lack and Lack 1951), burning (Blackford 1955, Bock and Lynch 1970, Marshall 1957) and other means (Karr 1968, Yeager 1955). The effects of the various treatments on the breeding bird communities of the clearcut, severely thinned, irregular strip shelterwood, and silviculturally cut plots were pronounced (table 3 ). The openings made by cutting led to an increase of those species which appear to require a more open habitat (rock wren, robin, western wood pewee, and yellow-rumped warbler) and a decrease or elimination of those species which appear to require dense foliage (western flycatcher, red-faced warbler, hermit thrush, black-headed grosbeak, and pygmy nuthatch). Cutting the irregular strip shelterwood and silviculturally cut sites increased population density and slightly changed species composition when compared to the control site.

These results tend to contradict the idea that the greatest bird species diversity and population densities are in the climax forest (Johnston and Odum 1956, Karr 1968, Kendeigh 1948, Shugart and James 1973). Studies have shown that population densities were highest in intermediate stands (Bond 1957, Kendeigh 1946). Karr (1968) noted a decline in species richness and density in the last forest stage in Illinois. The impact of fire on vegetation and, in turn, on breeding bird populations was studied in chaparral (Lawrence 1966), in pine-oak woodland (Marshall 1963), and in ponderosa pine (Lowe et al. 1978). The more open habitat produced by burning in both vegetative types led to an increase in numbers of species and density with some changes in species composition. A significant increase in bird species richness and abundance followed logging in the Douglas-fir region of northwestern California (Hagar 1960) and in a giant sequoia forest of northern California (Kilgore 1971). Similarly, the cutting and/or logging of the habitat in the ponderosa pine forest increased bird population densities and altered species composition.

Bird pairs on all the treated plots except the clearcut site were more highly packed (the average amount of foliage volume per average pair of birds was smaller) than bird pairs on the control plot. Pair packing on the severely thinned plot was 67,800 cubic feet per pair, whereas on the irregular strip shelterwood plot there was 64,200 cubic feet of foliage per pair. In contrast, on the control site, there was 251,400 cubic feet of foliage per pair, and on the silviculturally cut site, there was 140,300 cubic feet of foliage per pair. On the severely thinned plot, bird pair packing was higher than on the control site because of the great reduction in foliage which was not accompanied by a proportional decrease in population density. In fact, on the irregular strip shelterwood plot, not only was the amount of available foliage reduced by two-thirds, but the densities increased as well, resulting in much higher pair packing. Birds on both these heavily treated watersheds might come into greater potential competition with each other.

Bird pairs on both the severely thinned and the irregular strip shelterwood plots were equally packed, suggesting that approximately 65,000 cubic feet of foliage is the minimum required by a given pair. If the bird community on the control 
Table 3.-Breeding bird composition of the study areas (2 year average pairs per 40 ha)

\begin{tabular}{|c|c|c|c|c|c|}
\hline Species & Control & $\begin{array}{c}\text { Silviculturally } \\
\text { cut }\end{array}$ & $\begin{array}{l}\text { Irregular } \\
\text { strip }\end{array}$ & $\begin{array}{l}\text { Severely } \\
\text { thinned }\end{array}$ & Clearcut \\
\hline \multicolumn{6}{|l|}{ Pickers and gleaners } \\
\hline Mountain chickadee (CD) & 5.3 & 5.3 & 4.5 & 0.8 & ...- \\
\hline Pygmy nuthatch (CD) & 14.3 & 16.5 & 6.0 & 1.9 & --.- \\
\hline House wren (CD) & -... & & 3.0 & -..- & --- \\
\hline Solitary vireo $(\mathrm{FN})$ & 3.0 & 6.0 & 9.0 & 6.0 & ---- \\
\hline Yellow-rumped warbler (FN) & 1.5 & 12.0 & 3.0 & 1.5 & --- \\
\hline Grace's warbler (FN) & 9.0 & 19.1 & 14.3 & 6.8 & -..- \\
\hline Red-faced warbler (GN) & 3.0 & -..- & ...- & -... & .... \\
\hline Western tanager (FN) & 1.5 & 5.6 & 3.0 & -.-- & $\cdots-$ \\
\hline Hepatic tanager (FN) & $\ldots$. & .... & 1.5 & .... & -..- \\
\hline Guild Density & 37.6 & 64.5 & 44.3 & 17.0 & $---\cdot$ \\
\hline \multicolumn{6}{|l|}{ Ground feeders } \\
\hline Robin (FN) & -... & 3.0 & 5.3 & 3.8 & 0.5 \\
\hline Rufous-sided towhee (FN) & -.-- & $\cdots-$ & $\cdots$ & $\cdots-$ & 6.9 \\
\hline Chipping sparrow (FN) & 2.3 & 6.0 & 9.0 & 4.5 & -..- \\
\hline Mourning dove $(\mathrm{FN})$ & 3.0 & 1.5 & --- & 5.3 & $\ldots-$ \\
\hline Rock wren (GN) & .... & .... & 7.2 & 4.5 & 5.0 \\
\hline Hermit thrush (GN) & 1.9 & 0.4 & ...- & ---- & $\cdots$ \\
\hline Gray-headed junco (GN) & 15.0 & 18.8 & 11.3 & 6.4 & 1.8 \\
\hline Guild Density & 22.2 & 29.7 & 32.8 & 24.5 & 14.2 \\
\hline \multicolumn{6}{|l|}{ Hammerers and tearers } \\
\hline Common flicker (CD) & 3.0 & 3.0 & 3.4 & 3.0 & 0.8 \\
\hline Hairy woodpecker (CD) & 3.0 & 3.0 & 4.5 & 2.3 & -... \\
\hline Acorn woodpecker (CD) & ...- & -..- & .... & 3.0 & ...- \\
\hline White-breasted nuthatch (CD) & 6.8 & 11.3 & 10.5 & 7.5 & ---- \\
\hline Steller's jay (FN) & 7.5 & 4.5 & 5.3 & 5.3 & $-\cdots-$ \\
\hline Black-headed grosbeak (FN) & 3.3 & 3.0 & 1.5 & $\cdots \cdot$ & $\cdots$ \\
\hline Guild Density & 23.6 & 24.8 & 25.2 & 21.1 & 0.8 \\
\hline \multicolumn{6}{|l|}{ Aerial feeders } \\
\hline Western flycatcher (CD) & 4.9 & 4.2 & .... & $\cdots-$ & $\cdots$ \\
\hline Western wood pewee (FN) & --.- & 2.3 & 9.0 & 3.0 & $\cdots$ \\
\hline Say's phoebe (FN) & .... & -... & 1.5 & $\cdots-$ & $\cdots$ \\
\hline Violet-green swallow (CD) & $8: 3$ & 8.3 & 3.0 & $\cdots$ & $\cdots$ \\
\hline Western bluebird (CD) & 4.5 & 7.9 & 13.5 & 5.8 & $\ldots$ \\
\hline Mountain bluebird (FN) & -.-- & $\cdots \cdot$ & $-\cdots-$ & $\cdots-\cdot$ & 0.5 \\
\hline Broad-tailed hummingbird (FN) & 6.0 & 4.1 & 12.0 & 9.8 & -..- \\
\hline Common nighthawk (GN) & 3.0 & 1.5 & 3.0 & 3.0 & $\ldots$ \\
\hline Guild Density & 26.7 & 28.3 & 42.0 & 21.6 & 0.5 \\
\hline \multicolumn{6}{|l|}{ Nesting guilds } \\
\hline Cavity and depression (CD) & 50.1 & 59.5 & 48.4 & 24.3 & 1.3 \\
\hline Foliage nesters (FN) & 37.3 & 67.1 & 74.4 & 46.0 & 12.4 \\
\hline Ground nesters (GN) & 22.7 & 20.7 & 21.5 & 13.9 & 1.8 \\
\hline Total density & 110.1 & 147.3 & 144.3 & 84.2 & 15.5 \\
\hline Diversity $\left(H^{\prime}\right)$ & 2.83 & 2.80 & 2.94 & 2.81 & 1.35 \\
\hline Evenness & 0.93 & 0.91 & 0.94 & 0.96 & 0.69 \\
\hline Richness & 21 & 22 & 23 & 19 & 7 \\
\hline
\end{tabular}

plot was as highly packed as that on the severely thinned plot, it should support approximately 425 pairs per 100 acres. Since foliage volume does not appear to be the limiting factor, then factors such as territoriality, food supply, and lack of openings or other habitat configurations may limit bird populations.

The foraging and nesting guilds were variously affected by forest cutting and logging (table 3). The pickers and gleaners and the ground feeders increased in population density on the silvicul- turally cut and irregular strip shelterwood plots. The aerial feeders increased by $57 \%$ on the irregular strip shelterwood plot in response to the open strip areas, whereas the hammerers and tearers remained relatively stable on all the forested watersheds. All the foraging guilds, except for the ground feeders, were virtually eliminated from the clearcut plot. The cavity and depression nesters and ground nesters greatly decreased in population density on the severely thinned plot, whereas the foliage nesters greatly 
increased in population density on the silviculturally cut and irregular strip shelterwood plots. Interestingly, the majority of the ground feeders on the clearcut plot were also foliage nesters. These birds used the Gambel oak saplings that were growing throughout the area for nesting substrate. The cavity nesters which also use cavities for roosting comprised between $60 \%$ and $94 \%$ of the wintering bird community (Szaro 1976).

Eleven species (solitary vireo, pygmy nuthatch, Grace's warbler, white-breasted nuthatch, common flicker, hairy woodpecker, steller's jay, grayheaded junco, chipping sparrow, broad-tailed hummingbird, and western bluebird) were present on all the forested plots during the study. The common nighthawk was observed on all areas in 1975 but was not found on the silviculturally cut plot in 1974. Several species increased their density in their typical habitat (the foliage) on the treated plots. Of the species found on all the forested plots, eight (all but the common flicker, hairy woodpecker, and pygmy nuthatch) had their highest population densities on treated plots indicating density increases in response to openness. In contrast, population densities of five species (red-faced warbler, pygmy nuthatch, western flycatcher, violet-green swallow, and black-headed grosbeak) were significantly reduced with heavy alteration of the habitat. The rock wren, robin, and western wood pewee bred only on treated plots, whereas the acorn woodpecker was found exclusively on the severely thinned plot. These species probably required the increased openness of the habitat. The common flicker, hairy woodpecker, and steller's jay maintained relatively stable densities on both the control and treated plots.

Bird species diversity and species richness in the ponderosa pine forest were not significantly affected (based on an importance criterion of at least a $15 \%$ difference) by treatment except on the clearcut plot. Bird population densities were significantly increased by forest cutting on the silviculturally cut and irregular strip shelterwood plots and were significantly decreased on the severely thinned and clearcut plots. For a more detailed description of treatment and climatic effects see Szaro (1976).

\section{Literature Cited}

Balda, Russell P. 1969. Foliage use by birds of the oak-juniper woodland and ponderosa pine forest in southeastern Arizona. Condor 71:399-412.
Balda, Russell P. 1975. The relationship of secondary cavity nesters snag densities in western coniferous forests. USDA For. Serv. Wild. Habitat Tech. Bull. No. 1, 37 p.

Beecher, William J. 1942. Nesting birds and the vegetative substrate. Chicago Ornithol. Soc., Chicago.

Blackford, John L. 1955. Woodpecker concentration in burned forest. Condor 57:28-30.

Bock, Carl E., and James F. Lynch. 1970. Breeding bird populations of burned and unburned conifer forest in the Sierra Nevada. Condor 72:182-189.

Bond, Richard R. 1957. Ecological distribution of breeding birds in the upland forests of southern Wisconsin. Ecol. Mongr. 27:351-382.

Brown, Harry E., Malchus B. Baker, Jr., James J. Rogers, Warren P. Clary, J. L. Kovner, Frederic R. Larson, Charles C. Avery, and Ralph E. Campbell. 1974. Opportunities for increasing water yields and other multiple use values on ponderosa pine forest lands. USDA For. Serv. Res. Pap. RM-129, 36 p. Rocky Mt. For. and Range Exp. Stn., Fort Collins, Colo.

Cottam, Grant, and J. T. Curtis. 1956. The use of distance measures in phytosociological sampling. Ecology 37:451-469.

Hagar, Donald C. 1960. The interrelation of logging, birds, and timber regeneration in the Douglas-fir region of northwestern California. Ecology 41:116-125.

Johnston, David W., and Eugene P. Odum. 1956. Breeding bird populations in relation to plant succession in the Piedmont of Georgia. Ecology 37:50-62.

Karr, James R. 1968. Habitat and avian diversity on strip-mined land in east-central Illinois. Condor 70:348-357.

Kendeigh, S. Charles 1944. Measurement of bird populations. Ecol. Monogr. 14:67-106.

Kendeigh, S. Charles 1946. Breeding birds of the beech-maple-hemlock community. Ecology 27:226-244.

Kendeigh, S. C. 1948. Bird populations and biotic communities in northern lower Michigan. Ecology 29:101-114.

Kilgore, Bruce M. 1971. Response of breeding bird populations to habitat changes in a giant sequoia forest. Am. Midl. Nat. 85:135-152.

Lack, David. 1933. Habitat selection in bords with special reference to the effects of afforestation on the Breckland avifauna. J. Animal Ecol. 2:239-262.

Lack, David. 1939. Further changes in the Breckland avifauna caused by afforestation. J. Animal Ecol. 8:277-285. 
Lack, David, and Elizabeth Lack. 1951. Further changes in bird life caused by afforestation. J. Animal Ecol. 20:173-179.

Lawrence, George E. 1966. Ecology of vertebrate animals in relation to chaparral fire in the Sierra Nevada foothills. Ecology 47:278-291.

Lowe, Philip O., Peter F. Ffolliott, John H. Dieterich, and David R. Patton. 1978. Determining potential wildlife benefits from wildfire in Arizona ponderosa pine forests. USDA For. Serv. Gen. Tech. Rep. RM-52, 12 p. Rocky Mt. For. and Range Exp. Stn., Fort Collins, Colo.

MacArthur, Robert H. 1958. Population ecology of some warblers of northeastern coniferous forests. Ecology 39:599-619.

MacArthur, Robert H., and James W. MacArthur. 1961. On bird species diversity. Ecology 42:594-598.

MacArthur, Robert H., James W. MacArthur, and J. Preer. 1962. On bird species diversity. II. Prediction of bird census from habitat measurements. Am. Nat. 96:167-174.

MacArthur, R. H., H. Recher, and M. Cody. 1966. On the relation between habitat selection and species diversity. Am. Nat. 100:319-332.

Marshall, Joe T., Jr. 1957. Birds of pine-oak woodland in southern Arizona and adjacent Mexico. Pac. Coast Avifauna 32:1-125.
Marshall, Joe T., Jr. 1963. Rainy season nesting in Arizona. Proc. Int. Ornithol. Congr. 13:620-622.

Morse, Douglas H. 1967. Competitive relationships between parula warblers and other species during the breeding season. Auk 84:490-502.

Recher, Harry 1969. Bird species diversity and habitat diversity in Australia and North America. Am. Nat. 103:75-80.

Shannon, C. E., and W. Weaver. 1948. The mathematical theory of communication. Univ. Ill. Press, Urbana. $117 \mathrm{p}$.

Shugart, Herman Henry, and Douglas James. 1973. Ecological succession of breeding bird populations in northwestern Arkansas. Auk 90:62-77.

Szaro, Robert C. 1976. Population densities, habitat selection, and foliage use by the birds of selected ponderosa pine forest areas in the Beaver Creek Watershed, Arizona. Ph.D. diss. Northern Ariz. Univ., Flagstaff. 264 p.

Williams, John A., and Truman C. Anderson, Jr. 1967. Soil survey of Beaver Creek Area, Arizona. USDA For. Serv. and Soil Conserv. Serv. Washington, D.C. [Available from Sup. Doc., U.S. Gov. Print Off., Washington, D.C. 20402]. $75 \mathrm{p}$.

Yeager, Lee E. 1955. Two woodpecker populations in relation to environmental change. Condor 57:148-153. 


\section{Appendix}

\section{Bird Common and Scientific Names}

\section{Common name}

Mourning dove

Common nighthawk

Broad-tailed hummingbird

Common flicker

Acorn woodpecker

Hairy woodpecker

Say's phoebe

Western flycatcher

Western wood pewee

Violet-green swallow

Steller's jay

Mountain chickadee

White-breasted nuthatch

Pygmy nuthatch

House wren

Rock wren

American robin

Hermit thrush

Western bluebird

Mountain bluebird

Solitary vireo

Yellow-rumped warbler

Grace's warbler

Red-faced warbler

Western tanager

Hepatic tanager

Black-headed grosbeak

Gray-headed junco

Rufous-sided towhee

Chipping sparrow

\section{Scientific name}

Zenaida macroura

Chordeiles minor

Selasphorus platycercus

Colaptes auratus cafer

Melanerpes formicivorous

Picoides villosus

Sayornis saya

Empidonax difficilis

Contopus sordidulus

Tachycineta thalassina

Cyanocitta stelleri

Parus gambeli

Sitta carolinensis

Sitta pygmaea

Troglodytes aedon

Salpinctes obsoletus

Turdus migratorius

Catharus guttatus

Sialia mexicana

Sialia currucoides

Vireo solitarius

Dendroica coronata auduboni

Dendroica graciae

Cardellina rubrifrons

Piranga ludoviciana

Piranga flava

Pheucticus melanocephalus

Junco caniceps

Pipilo erythrophthalmus

Spizella passerina

\section{Tree Common and Scientific Names}

\section{Common name}

Ponderosa pine

Alligator juniper

Gambel oak
Scientific name

Pinus ponderosa

Juniperus deppeana

Quercus gambellii 
䇾高

$\Phi$

栗它部

प这

की

ठ․

क्ष

되용

s.

बำ

- 용

굴

的晋芝

ค ㅊ

चี है

i

承

䒕

$\approx \stackrel{\sim}{*}$

ن.

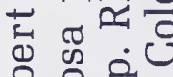

잉

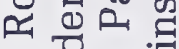

○施吾

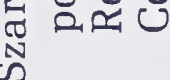

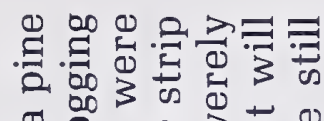

ชึ응

क्ष.

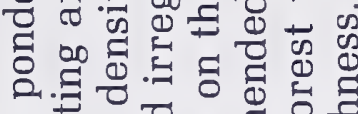

苛

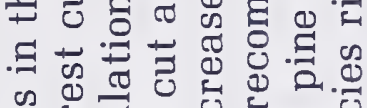

क

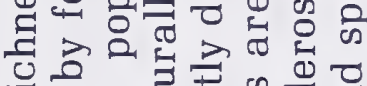

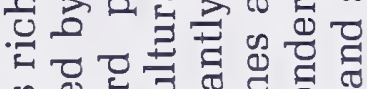

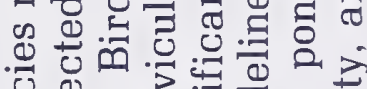

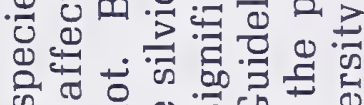

की 0 की

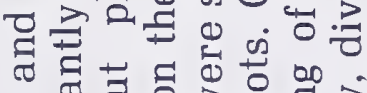

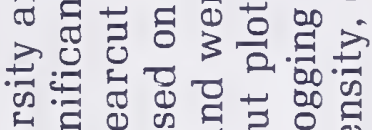

망

告

क 苔引.

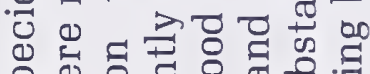

के

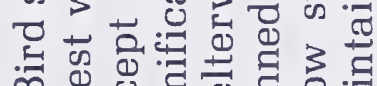

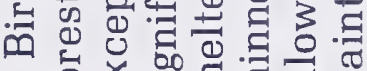

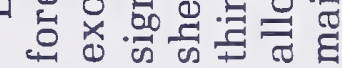

.

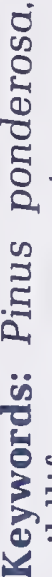

क्षे

它站

严红

눙

요의.

远

由ิ

S.

बิ증

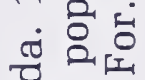

๓

무

च हี

की

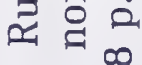

ซี ริ

๘

$\dot{0} \cdot \sum^{1}$

두요의

की 0

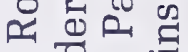

잉

ผ

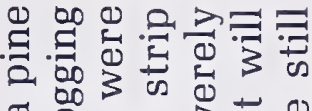

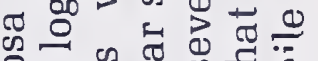

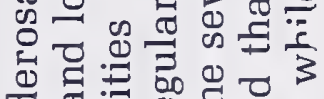

क

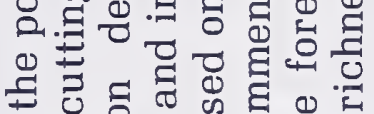

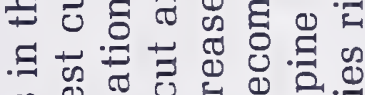

क $\frac{\pi}{3} 0$ 出

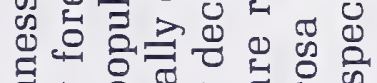

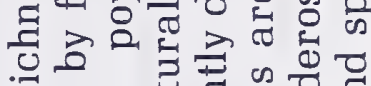

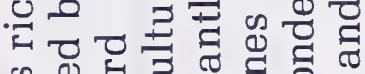

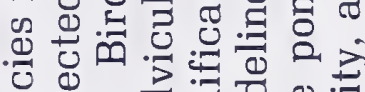

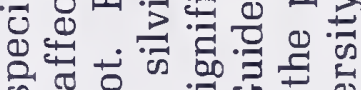

का 20 을 की

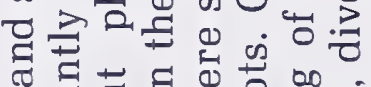

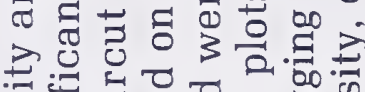

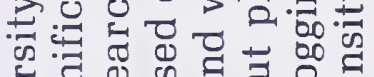

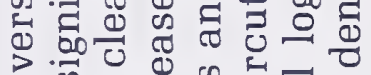

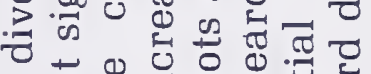

ه 흠

Ш

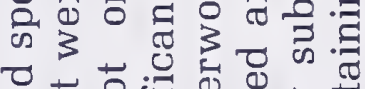

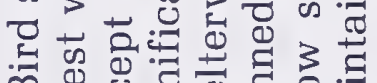

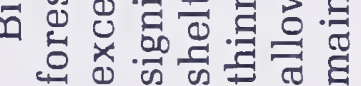

:

.

0
0
0
0
0
0
0
0
0
0
0
0
0
0
0
0
0 $\rightarrow$

क्ष

这

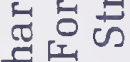

पै $4 \dot{2}$

की

割。

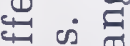

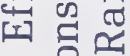

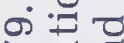

ลิ สำ

$\rightarrow$ 용

खृ 을

品品忘

.

워 0

ह ह 능

议

承完

$\infty$

ฮี ธิ

ำ

U.

舟

슨

०

ชี

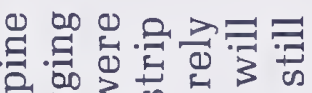

$\infty_{\infty}^{\infty} 3$ का ए

क्ष

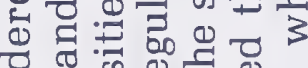

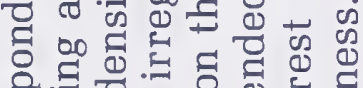

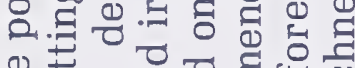

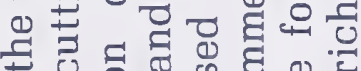

$\Xi$ 西类

क

\&

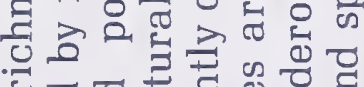

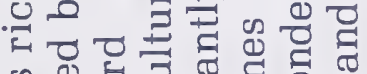

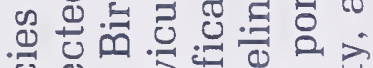

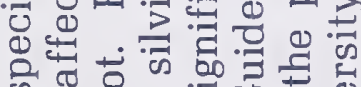

क के कण

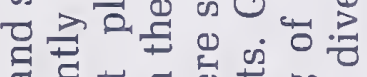

๙

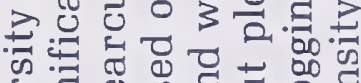

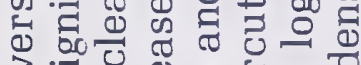

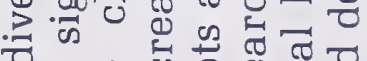

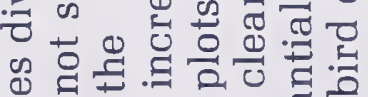

잉

की

क 3 可 3 क क

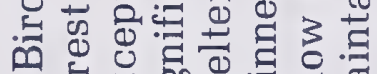

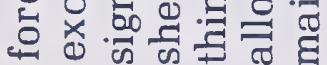

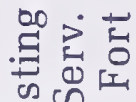

$\stackrel{1}{\circ}$

它焉

पे

क्षि 뙤

品

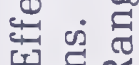

เ

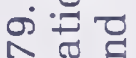

윽 즐

응

तु ฉ․

क्ष

두

를

on $\infty$

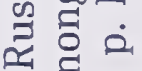

등

ن.

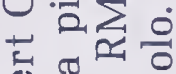

क

政西

영

क 20

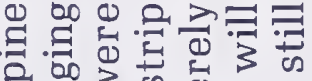

人

땡으 क्ष

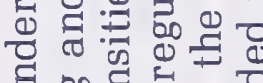

क०

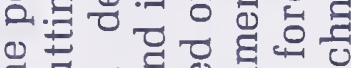

ङ

.

की

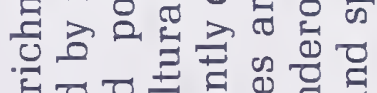

च

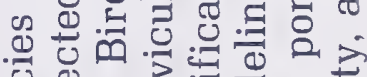

进

के वे के

열

ชี

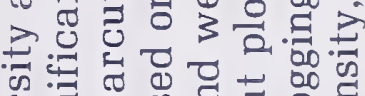

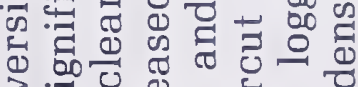

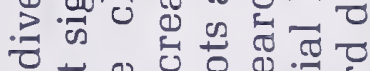

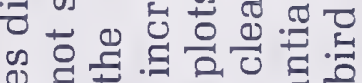

.

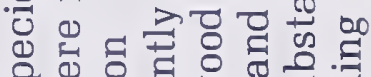

क

은

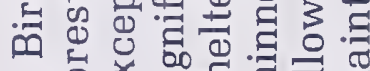

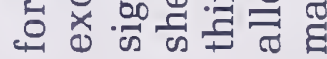

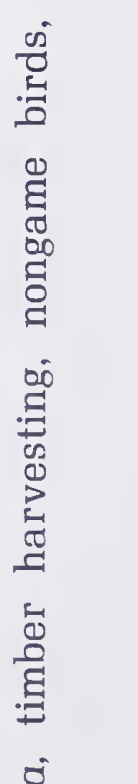

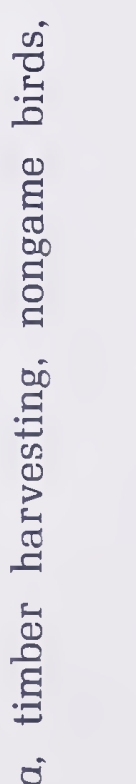

告

:

วิ हี

路

$\ddot{g}$

光

3 

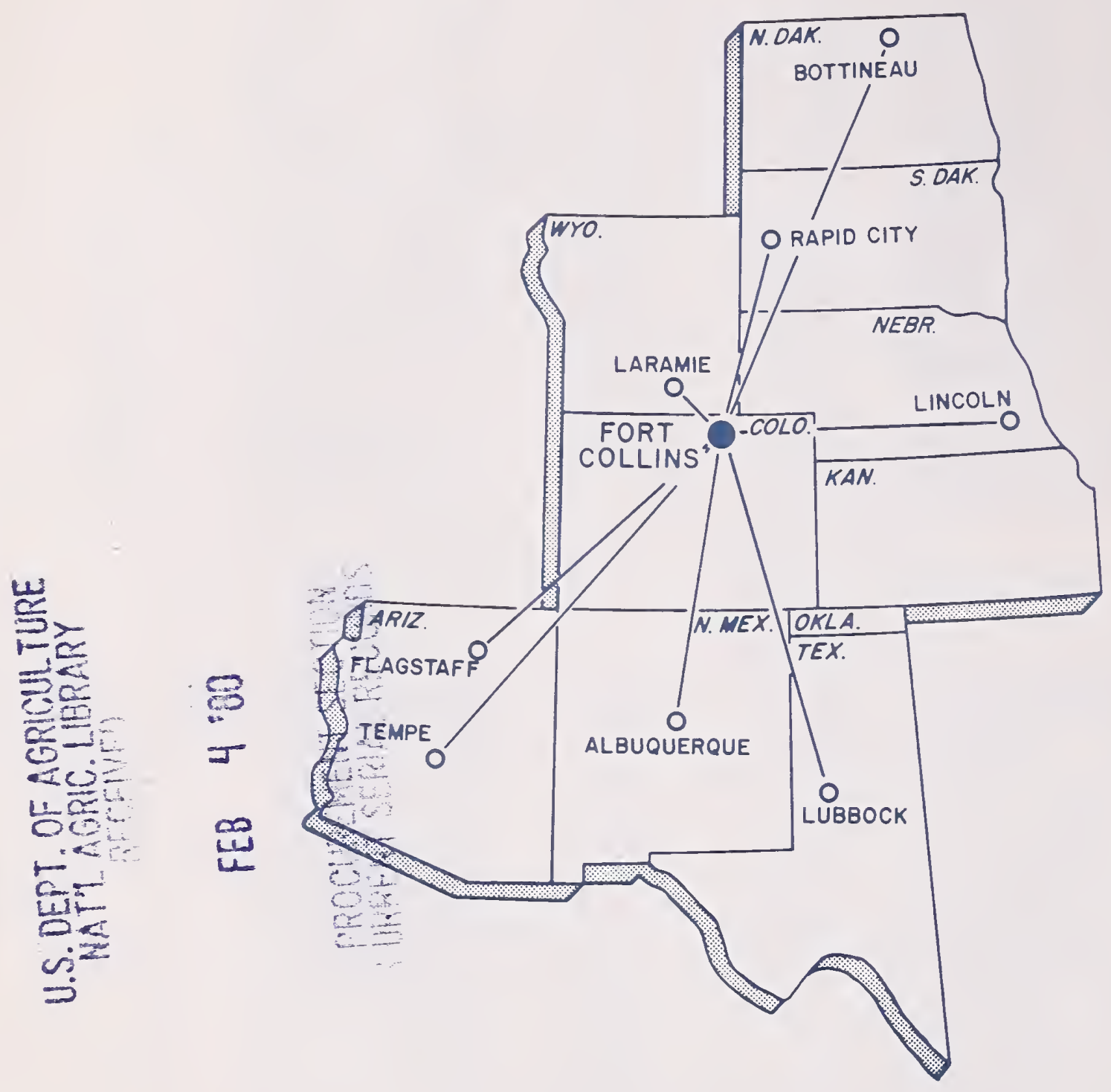